\title{
Ground Levels in Bihar in relation to the Earthquake of January I5, I934
}

\author{
By Col. Sir Sidney Burrard, Bt., F.R.s.
}

$\mathrm{I}^{\mathrm{N}}$ 236, Dr. de Graaff Hunter has endeavoured to show that the surface of the plains where the earthquake of January 15 occurred in India had been proved by levelling to have been rising in height throughout the present age, at the rate of $4 \frac{1}{2} \mathrm{ft}$. per century. This conclusion is so important that I feel justified in submitting my reasons for questioning it. Dr. Hunter bases his theory on the results of levelling, but these are not confirmed by the geographical facts of Bihar. The accuracy of levelling is estimated from the agreement between two independent levellers. Although they take independent observa. $\mathrm{N}$ an article published in NATURE of February 17, p.

they may reach the sea along curves of least resistance. The adjustment of the surface to the rivers is very delicate; and it is not possible to say that either is the governing factor : their co-operation is perfect.

The rivers have to carry immense volumes of water from the Himalayan snows across densely inhabited level plains, and although they have the guidance of skilled engineers, a constant rise of the ground level across their paths would upset their balance and deflect their courses. No such results have been observed in confirmation of the levelling theory.

It may even be doubted whether a flat surface overlying alluvial depths could possibly be raised $4 \frac{1}{2} \mathrm{ft}$. per century as the levelling theory assumes. If any area of alluvium were to be raised above the normal level of the surface, or above the normal saturation level, the rise would probably be converted into "blown sand', and would be re. moved by winds.

Dr. Hunter's conclusion that the surface of the earthquake area has been rising $4 \frac{1}{2} \mathrm{ft}$. a century is based upon three levelling results - Pirpainti, Benares and Dinajpur.

Pirpainti Levelling. A discrepancy of $3 \cdot 178$ feet was discovered at Pirpainti, when in 1929 a new line of levels intersected the old line of 1862. Dr. Hunter believes that this levelling discrepancy of $3 \cdot 178$ feet denotes a rise in the height of Pirpainti

FIG. 1. Rivers of Bihar.

tions, they work together, and there are sources of error which affect them both.

The history of levelling has placed on record several examples in Egypt, India and France of errors being accumulated and being only discovered when the levelling was connected with mean sealevel. We have no mean sea-level in Bihar, and the only check here upon levelling errors is provided by the rivers (Fig. 1). The numerous rivers that traverse the flat plains are governed, like sea-level, by gravitation. The surface of the plains differs in form from that of the sea, in that they have a gentle slope from north to south and a still gentler slope from west to east. The combination of these two slopes compels the numerous rivers, as soon as they escape from the Himalaya, to follow courses that converge upon the south-east corner of Bihar. It is perhaps not strictly correct to say that the slopes determine the courses of the rivers, for the rivers have created the slopes. If Bihar were at sea-level, its surface would be spheroidal, but as it is raised above the sea by two hundred feet of unconsolidated alluvium, the rivers have so shaped its surface that such faith in the accuracy of this levelling. Pirpainti is a station of the East India Railway : the levelling along this railway was carried out in 1862, the levellers were inexperienced, their instruments were primitive. When the bench-mark was originally cut at Pirpainti station, it was not intended to be a standard datum for scientific observations. No pendulum observer would take observations in this railway station. I feel that the discrepancy of $\mathbf{3} \cdot 178$ feet at Pirpainti may be due to an accumulation of errors arising from the instability of the site, from the inexperience of the levellers in 1862, and from the 'secondary' character of the check levelling in 1929.

Benares Levelling. A discrepancy of $2 \cdot 170$ feet was discovered at Benares when in 1916 a new line of levelling intersected the old line of 1863. This discrepancy is attributed by Dr. Hunter to the rise of Benares between 1863 and 1916. The levelling in 1863 to Benares was a continuation of the Pirpainti line, and its result is dependent on Pirpainti. The levelling of 1916, which first disclosed the discrepancy between 1862 and 1929. I find it difficult to place 
of $2 \cdot 170$ feet at Benares, was brought from Calcutta across the mountainous region of Hazaribagh. This levelling was carefully observed, but no levelling over mountains can have a high degree of accuracy. The rays to the fore and aft staves are exposed to unequal refraction. I do not think that the level of the flat plains of Bihar can be tested by mountain levelling. A bench-mark on Hazaribagh rock would be a reliable standard datum for Bihar, provided it were not high up, but on a steep ascent levelling accuracy deteriorates.

Dinajpur Levelling. In 1900 (after the publication by the Geological Survey of the memoir on the great earthquake of 1897) a line of levels was carried across Bengal from south to north, from Calcutta to Dinajpur, by Capt. H. L. Crosthwait and Lieut. H. M. Cowie : this line was in every way scientific, and the height of Dinajpur was determined as accurately as was possible. In 1925 a new line of levels intersected the 1900 line at Dinajpur. The discrepancy between the 1900 and the 1925 results was 0.963 foot.

Dr. Hunter assumes this discrepancy of 0.963 foot to be due to the rise of Bengal between 1900 and 1925 , and he converts the observed error of 0.963 into a theoretical rise of 4 feet in 100 years. Dr. Hunter's procedure is based upon the assumption that there was no levelling error on either of the lines that met at Dinajpur. Such an assumption is contrary to experience. If we bear in mind that the 1925 level-line had to pass through the streets of Calcutta and to cross the Hugli, and that both the 1900 and 1925 lines had to cross the main stream of the Ganges, we may feel justified in thinking that a discrepancy of 0.963 foot in 500 miles is within the limits of accumulated error.

The safest way of proving whether Dinajpur has risen in height would be to re-observe the whole levelling line of 1900 , bench-mark by bench-mark, from Calcutta to Dinajpur. A single intersection of this line by another line does not furnish convincing evidence.

By Dr. J. De GraafF Hunter, c.I.E.

MY short account of the results of spirit-levelling in Bengal, accumulated between 1862 and 1930, and their interpretation, are given in the Survey of India Geodetic Report $(6,104-6)$. In such a report considerations of space preclude the inclusion of every corroborative detail which the full records of the work contain.

Sir Sidney Burrard, not quite rightly, says that my theory rests on three levelling results. Actually it rests on a group of levelling circuits all giving evidence in the same direction; but the results which he cites are certainly important. The first of these does not rest on the single bench-mark at the railway station. If reference is made to pp. 71-97 loc. cit., it will be seen that two bench-marks, a quarter of a mile apart, were picked up at Pirpainti and gave results agreeing within $0.05 \mathrm{ft}$. Further, the con. nexion with Pirpainti was made after results at Bhagalpur and Luckeesarai had indicated a rise of more than two feet; which the Pirpainti connexion confirmed. The 'secondary' levelling of 1929 is almost of the same type as what was formerly (before the introduction of levelling of high precision) known as levelling of precision.

The Benares result depends in part on Pirpainti, now justified, and on modern levelling through the mountainous region of Hazaribagh. In the case of a much more mountainous Himalayan circuit, I investigated the refraction anomaly, and found it to be trivial, a much more important error being due to the variation in length of the wooden levelling staves, during the course of the day. This tends to increase with the total amount of ups and downs of the line, which in the case of the Hazaribagh line are not enough to justify rejection of results, though nowadays we should employ invar staves in such a case.

Careful consideration was given to the errors which might naturally be expected in all these levelling lines, including those on which the Dinajpur result was based; and the special difficulties of wide river crossings were not forgotten.

The geographical evidence is sufficient to cause Sir Sidney to mistrust the levelling of 1862 because the workers were inexperienced and had primitive instruments ; and more modern work when it passes through mountains such as occur in Hazaribagh. I cannot bring myself to discount all the spirit levelling in this way and prefer to judge it by its own internal and unbiased evidence, not omitting to consider the 'systematic' error as usually evaluated.

The spirit levelling evidence is limited to the area of its observations, and so gives only a partial picture. This covers roughly the triangle CalcuttaDarjeeling-Benares. So the contours of my chart (NATURe, Feb. 17, p. 236) extend little into the area of Sir Sidney's sketch of the rivers of Bihar. Most of this river area may have risen almost uniformly, which would certainly be in keeping with my area of underloading. Why, then, should extensive geographical changes be expected, or their absence be regarded as in opposition to the results of much spirit-levelling ?

In my opinion much of the so-called 'systematic error' in levelling must be due to secular changes of ground level operating during the progress of the lines forming a circuit. On this account we are probably assessing the precision of spirit levelling below its true value.

\section{Research in the Sea*}

$\mathrm{T}$ HE latest available issue of the Journal of the Marine Biological Association contains many valuable memoirs, being records of research undertaken chiefly at the Plymouth Marine Laboratory but also at the Scottish Marine Station, Millport, the Port Erin Marine Station, Isle of Man, and the Dove Marine Laboratory, Cullercoats, Northumberland. The whole is admirably planned and emphasises the fact that oceanography in its broadest sense is the object of all the work done in these laboratories, that is to say, the study of the sea and its contents both animate and inanimate and of all factors which influence these, centring round the fish itself. It is impossible nowadays to separate pure science from the practical side, or to say that any matter connected with the sea is irrelevant to its study, and we find these researches carried on in the marine laboratories of Great Britain tend more and more to fit into one another and show real progress in general knowledge of the interpretations of marine phenomena.

A glance at the subject matter will show how varied are the contents, but yet how well everything

* Journal of the Marine Biological As8ociation, N.S., 19, No. 1, August 1933, pp. 1-286. (Plymouth : The Association.) 